\title{
International trends in grant and fellowship funding awarded to women in neurosurgery
}

\author{
*Kimberly Wang, BS, ${ }^{1,2}$ Archis R. Bhandarkar, BS,,2 Megan M. J. Bauman, MSc,, \\ Cecile Riviere-Cazaux, BS, ${ }^{1,2}$ Juliana Rotter, MD, ${ }^{1}$ Kristen M. Scheitler, MD, ${ }^{1}$ \\ Jaclyn J. Renfrow, MD, ${ }^{1}$ and Michelle J. Clarke, MD' \\ ${ }^{1}$ Mayo Clinic Department of Neurologic Surgery, and ${ }^{2}$ Mayo Clinic Alix School of Medicine, Rochester, Minnesota
}

\begin{abstract}
OBJECTIVE Metric tracking of grant funding over time for academic neurosurgeons sorted by gender informs the current climate of career development internationally for women in neurosurgery.

METHODS Multivariate linear trend analysis of grant funding awarded to neurosurgeons in the NIH and World Research Portfolio Online Reporting Tools Expenditures and Results (RePORTER) was performed. Traveling fellowships for international neurosurgery residents sponsored by the AANS and Congress of Neurological Surgeons (CNS) were also analyzed.
\end{abstract}

RESULTS Within the US, funding awarded to female neurosurgeons has remained static from 2009 to 2019 after adjusting for inflation and overall trends in $\mathrm{NIH}$ funding $(\beta=-\$ 0.3$ million per year, $p=0.16)$. Internationally, female neurosurgeons represented $21.7 \%(n=5)$ of project leads for World RePORTER grants. Traveling fellowships are also an important building block for young international female neurosurgeons, of which $7.4 \%(n=2)$ of AANS international traveling fellowships and $19.4 \%(n=7)$ of AANS/CNS pediatrics international traveling fellowships are women.

CONCLUSIONS Over the past decade, funding has increased in neurosurgery without a concordant increase in funding awarded to women. Recognition of this trend is essential to focus efforts on research and career development opportunities for women in neurosurgery. Worldwide, female neurosurgeons head one-fifth of the funded project leads and constitute a minority of international traveling fellowships awarded by organized neurosurgery.

https://thejns.org/doi/abs/10.3171/2020.12.FOCUS20846

KEYWORDS neurosurgery; grant; funding; $\mathrm{NIH}$; women; international

$\mathrm{T}$ HERE is a projected shortage of neurosurgeons despite predictions of increased neurological conditions in the aging population. ${ }^{1}$ To address this shortage, neurosurgery must continue to recruit and retain the brightest medical students, of which more than half currently enrolled in medical schools in the US are female. ${ }^{2}$ In 2008, Women in Neurosurgery (WINS) and the AANS leadership identified factors and strategies to promote the success of women in neurosurgery, including national and institutional mentorship programs and initiatives designed to alleviate perceptions of gender inequality and bias.,3,4

Measuring the value of mentorship through trends in metrics of success such as recruitment, scholarly productivity measured by the h-index, academic rank, and research funding is extremely important to identifying gender gaps and assessing the progress of women in the field. ${ }^{5-8}$ Within neurosurgery, the number of females in the field has slowly been increasing with time, and a key tool in this change has been mentorship. According to the literature, female medical students indicate that the lack of a female mentor would not dissuade them from entering a field, but rather having a mentor in general is one of the crucial components to retaining women in neurosurgery. ${ }^{5,9,10}$ Evidence suggests that female medical students are more likely to rank programs with higher numbers of female residents, and women in male-dominated residency programs are at higher risk for attrition in early residency. ${ }^{2,5,9,11}$

Access to mentorship from female academic neurosurgeons may increase the likelihood that current female residents pursue careers in research and academia. ${ }^{6,12-14}$ Early

ABBREVIATIONS CIHR = Canadian Institutes of Health Research; CNS = Congress of Neurological Surgeons; CPI = consumer price index; MBBS = Bachelor of Medicine, Bachelor of Surgery; MRC = Medical Research Council; NCI = National Center Institute; NHLBI = National Heart, Lung, and Blood Institute; NICHD = National Institute of Child Health and Development; NINDS = National Institute of Neurological Disorders and Stroke; PI = principal investigator; RePORTER = Research Portfolio Online Reporting Tools Expenditures and Results; SRC = Swedish Research Council; UK = United Kingdom; USD = US dollars; WINS = Women in Neurosurgery; WT = Wellcome Trust. SUBMITTED October 13, 2020. ACCEPTED December 15, 2020.

INCLUDE WHEN CITING DOI: 10.3171/2020.12.FOCUS20846.

${ }^{*}$ K.W. and A.R.B. share first authorship of this work. 
in career development, research funding shapes the overall landscape of scholarly productivity and inquiry, and trending funding with time establishes paths for career success and room for improvement within the upcoming generation of academic neurosurgeons. There is a paucity of prominent academic positions granted to female neurosurgeons, which decreases access to female mentorship and may ultimately affect the academic trajectories of female neurosurgeons to come. The objectives of this study are to analyze trends in successful research efforts measured through grant funding over time for female academic neurosurgeons, and to evaluate the current climate of career development for women in neurosurgery, both within the US and internationally.

\section{Methods}

\section{Data Sources and Data Abstraction}

The NIH Research Portfolio Online Reporting Tools Expenditures and Results (RePORTER; https://projectreporter.nih.gov/reporter.cfm) served as the source for grant data from the US. The NIH RePORTER is an online repository of intramural and extramural grants funded by the NIH since 1985. We queried the NIH RePORTER for all grants for which the principal investigator (PI) was affiliated with a department of neurosurgery (NIH RePORTER variable Department Type = "Neurosurgery") and grant money was awarded between fiscal years 2009 and 2019 (October 2008 to September 2019). A determination of the gender of the primary PI for each grant in our cohort was made using the pronouns (he/him/his or she/her/hers) found in their respective biosketches available online. Similarly, other information, such as the degrees held by primary PIs, as well as whether they were currently still in practice, was ascertained from online biosketches. ${ }^{15}$

The World RePORTER tool (https://worldreport.nih. gov/) served as the data source for international grant data. The World RePORTER is a publicly available online repository that reports information on grants from 2012 to 2018 that were awarded by the Bill \& Melinda Gates Foundation (BMGF), Canadian Institutes of Health Research (CIHR), European Commission (EC), European \& Developing Countries Clinical Trials Partnership (EDCTP), German Federal Ministry of Education and Research (BMBF), Japan Agency for Medical Research and Development (AMED), Medical Research Council (MRC), National Institutes of Health (NIH), Institut Pasteur (IP), Swedish International Development Cooperation Agency (SIDA), Swedish Research Council (SRC), and Wellcome Trust (WT). We queried the World RePORTER using the search terms "neuro" and "surgery" and abstracted additional biosketch information from online searches. Because grants recorded in the World RePORTER often involve multiinstitutional projects with multiple PIs at different centers, we chose to report distinct project-PI combinations in our analysis. ${ }^{16}$

Traveling fellowships for non-US, international neurosurgery residents sponsored by US-based neurosurgery organizations such as the AANS, Congress of Neurological Surgeons (CNS), and WINS were also included in our analysis. Awardee data were gathered for three prominent international fellowships: the AANS international traveling fellowship (award data available from 2006 to 2019), the AANS/CNS joint pediatrics section international traveling fellowship (award data available from 2000 to 2019), and the WINS/Greg Wilkins-Barrick Chair Visiting International Surgeon Award (award data available from 2013 to 2019$){ }^{17-19}$

\section{Statistical Analysis}

Award amounts were inflation-adjusted to 2019 US dollars (USD) using a ratio of consumer price indices (CPIs) between the fiscal year of the grant and 2019. For example, 2015 USD were converted to 2019 USD by multiplying by a factor of (CPI in 2019)/(CPI in 2015). CPIs for the years of our study period were collected from publicly reported data from the Federal Reserve Bank of Minneapolis. ${ }^{20}$ Award amounts in international currency were converted to USD using the exchange rate from X-Rates (https://Xrates.com) on January 1 of the award year and then were inflation-adjusted to 2019 USD, as above. ${ }^{21}$

Linear trend analysis was performed by fitting a multivariate linear regression model to the outcome of total yearly funding disbursements to female practicing neurosurgeons using the two independent variables of year, which ranged from 2009 to 2019, and total funding disbursements to all neurosurgeons in each year. This effectively separates out trends in funding awarded to women by adjusting for overall trends in funding. Coefficients from our multivariate regression model are reported with the symbol " $\beta$ " as per the statistics literature. A 1-sided Fisher's exact test was performed to assess whether the proportion of women awarded international traveling fellowships had increased during the period of 2010-2019 versus 2000-2009. All analyses were performed in R (version 4.0.1) and BlueSky Statistics (version 6.3.0).

\section{Results \\ US National Grant Data}

In our analysis of NIH RePORTER repository data from 2009 to 2019, 1002 yearly funding disbursements were allocated for 325 grants awarded to 180 distinct practicing neurosurgeons, amounting to $\$ 425$ million. Of these 180 practicing neurosurgeons, 19 women were awarded 29 distinct grants with a total of 103 yearly funding disbursements during the study period, which amounted to $\$ 33$ million. The group of female grant recipients consisted of 11 MDs, 5 MDs + PhDs, and 3 MDs + other graduate degrees (MBA, MAS, DVM). In terms of department affiliations, Stanford University, Northwestern University at Chicago, and the Icahn School of Medicine at Mount Sinai each had two practicing female neurosurgeon grant recipients, while Baylor College of Medicine, Johns Hopkins University, University of Alabama at Birmingham, University of California, Los Angeles, University of Cincinnati, University of Florida, University of Illinois at Chicago, University of Miami School of Medicine, University of Tennessee Health Science Center, University of Texas MD Anderson Cancer Center, University of WisconsinMadison, Washington University, and the Weill Medical College of Cornell University each had one. Of the dis- 
TABLE 1. Characteristics of grants awarded to practicing women neurosurgeons and their Pls

\begin{tabular}{|c|c|}
\hline Variable & Value (\%) \\
\hline \multicolumn{2}{|l|}{ PI characteristics $(n=19)$} \\
\hline \multicolumn{2}{|l|}{ Degrees } \\
\hline MD & $11(57.9)$ \\
\hline MD \& PhD & $5(26.3)$ \\
\hline MD \& some other degree & $3(15.8)$ \\
\hline \multicolumn{2}{|l|}{ Institution } \\
\hline Stanford University, Northwestern University at Chicago, and the Icahn School of Medicine at Mount Sinai* & $6(31.6)$ \\
\hline $\begin{array}{l}\text { Baylor College of Medicine, Johns Hopkins University, University of Alabama at Birmingham, University of California, Los } \\
\text { Angeles, University of Cincinnati, University of Florida, University of Illinois at Chicago, University of Miami School of Medicine, } \\
\text { University of Tennessee Health Science Center, University of Texas MD Anderson Cancer Center, University of Wisconsin- } \\
\text { Madison, Washington University, and the Weill Medical College of Cornell University† }\end{array}$ & $13(68.4)$ \\
\hline \multicolumn{2}{|l|}{ Grant characteristics $(n=29)$} \\
\hline \multicolumn{2}{|l|}{ Grant type } \\
\hline R01 & $10(34.5)$ \\
\hline K08 & $6(20.7)$ \\
\hline U01 & $3(10.3)$ \\
\hline F32 & $3(10.3)$ \\
\hline $\mathrm{R} 25$ & $2(6.9)$ \\
\hline Other (R56, R21, R13, P50, P01) & $5(17.2)$ \\
\hline \multicolumn{2}{|l|}{ Funding organization } \\
\hline NINDS & $18(62.1)$ \\
\hline $\mathrm{NCl}$ & $9(31.0)$ \\
\hline $\mathrm{NICHD}$ & $1(3.4)$ \\
\hline NHLBI & $1(3.4)$ \\
\hline
\end{tabular}

* Two practicing female neurosurgeon grant recipients at each institution, 6 total.

† One practicing female neurosurgeon grant recipient at each institution, 13 total.

tinct NIH grants awarded to women, there were $10 \mathrm{R} 01 \mathrm{~s}$ (34.5\%), 6 K08s (20.7\%), 3 U01s (10.3\%), 3 F32s (10.3\%), 2 R25s (6.9\%), and 5 others (R56, R21, R13, P50, and P01; 17.2\%). The National Institute of Neurological Disorders and Stroke (NINDS) was the funding organization of $18(62.1 \%)$ of these grants, the National Center Institute (NCI) for $9(31.0 \%)$, and the National Institute of Child Health and Development (NICHD) and National Heart, Lung, and Blood Institute (NHLBI) each were the funding organization for 1 grant (3.4\%; Table 1).

In our linear trend analysis of yearly funding disbursements to all neurosurgeons, we found a statistically significant increase in total inflation-adjusted funding awarded to practicing neurosurgeons from 2009 to $2019(\beta=+\$ 3.5$ million per year, $p=0.01$ ). After adjusting for this overall trend in a multivariate regression model, we did not find a similar increase in funding awarded to women from 2009 to 2019 ( $\beta=-\$ 0.3$ million per year, $p=0.16$; Fig. 1 ). This adjustment allowed us to separate increasing trends in overall NIH funding from trends in funding for women neurosurgeons.

\section{International Grant Data}

Of the 23 distinct project-PI pairs within the World RePORTER repository led by a PI who is a practicing neurosurgeon, 5 (21.7\%) were led by women neurosurgeons.
Projects were led by 15 neurosurgeons from Canada (65.2\%), 3 from India (13.0\%), 3 from the United Kingdom (UK; 13.0\%), 1 from Sweden (4.3\%), and 1 from Uganda (4.3\%). Nine project leaders had a Doctorate of Medicine (MD) or a Bachelor of Medicine, Bachelor of Surgery (MBBS) with $\mathrm{PhD}$ (39.1\%), 6 had an MD and a master's degree (MPH/MSc/MHSc, 26.1\%), and 8 had a medical degree alone (34.8\%). Of 13 project-PI pairs that reported funding amounts, the median award was $\$ 228,821$ (range $\$ 126,890-\$ 2,736,855)$ in 2019 USD (Table 2).

\section{International Traveling Fellowship Data}

A total of 27 AANS international traveling fellowships, 36 AANS/CNS joint pediatrics international traveling fellowships, and 13 WINS/Greg Wilkins-Barrick Chair Visiting International Surgeon awardees were included in our analysis (Table 3). Among these fellowships, $7.4 \%(\mathrm{n}=2)$ of AANS international traveling fellowships, $19.4 \%(n=7)$ of AANS/CNS joint pediatrics international traveling fellowships, and $100 \%(\mathrm{n}=13)$ of WINS/Greg Wilkins-Barrick Chair Visiting International Surgeon awardees were awarded to 21 women (Fig. 2; one woman was awarded twice). India was the most common home country among female grant awardees, representing $19.0 \%(n=4)$ of all female awardees, followed by Indonesia $(14.3 \%, \mathrm{n}=3)$, Germany $(9.5 \%, \mathrm{n}=2)$, Philippines $(9.5 \%, \mathrm{n}=2)$, Russia 


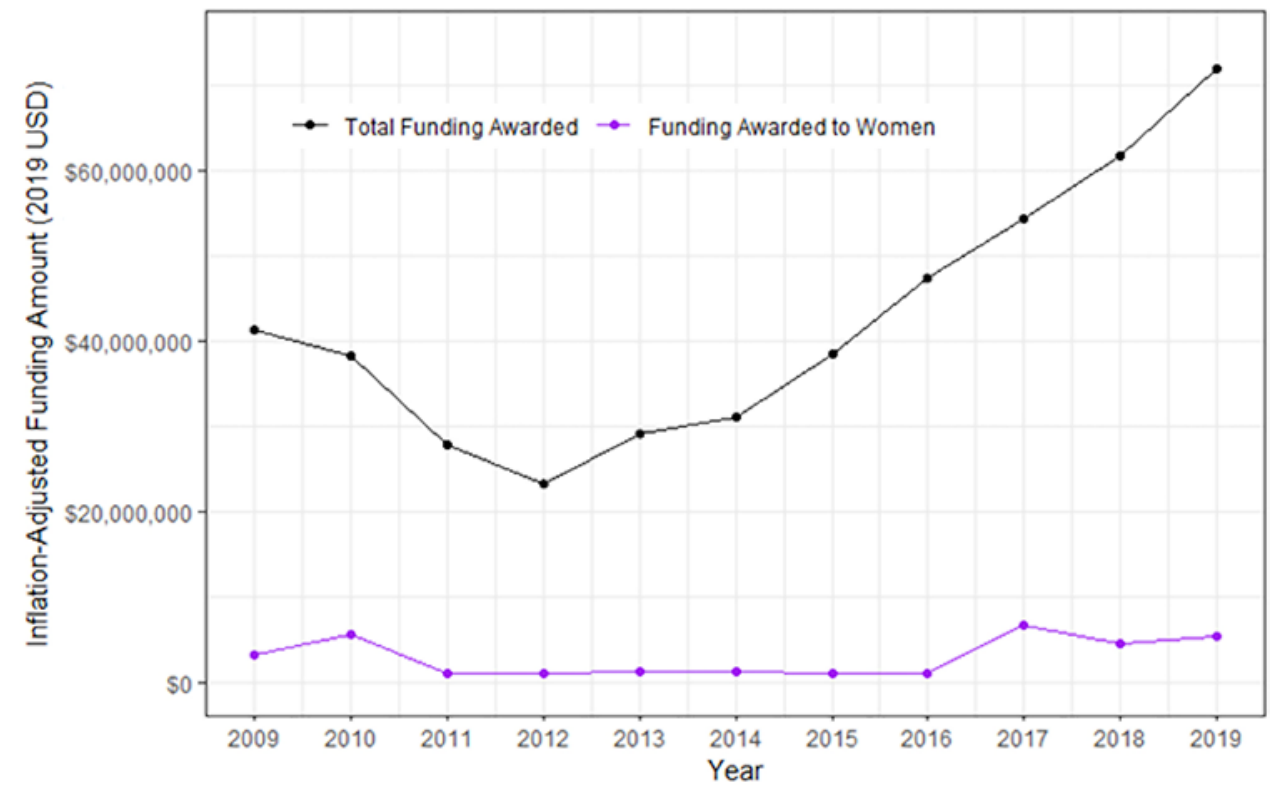

FIG. 1. Inflation-adjusted funding awarded to practicing female neurosurgeons in the US (2009-2019).

$(9.5 \%, \mathrm{n}=2)$, and Spain $(9.5 \%, \mathrm{n}=2)$. Excluding WINS fellowship awardees, we noted no statistically significant difference in the proportion of AANS international traveling fellowships and AANS/CNS joint pediatrics international traveling fellowships awarded to women during the period of 2010-2019 versus 2000-2009 (OR 1.37, p $=0.49$ ).

\section{Discussion}

The percentage of female practicing neurosurgeons who were awarded grants is consistent with the national average of women in neurosurgery $(10.56 \%$ compared to approximately $12 \%$ of neurosurgeons in the US and Canada). ${ }^{5}$ While funding awarded to practicing neurosurgeons increased over a 10 -year period at a rate of $\$ 3.5$ million per year, this same trend was not observed in funding allotted to women; rather, there was a slight decrease at a rate of $\$ 0.3$ million per year. Potential explanations include a decrease in the overall number of female research applicants for funding, a decreased grant renewal rate, or a decreased grant funding rate. Nevertheless, the inverse relationship between increased research funding in neurosurgery overall and decreased research funding allocated to female neurosurgeons warrants further investigation. Similar studies that have investigated trends in NIH funding among neurosurgeons did not adjust for inflation and overall trends in NIH as we have in our multivariate regression model, nor did they include recent data from the 2019 fiscal year., ${ }^{7}$

Our results are similar to those of previous studies investigating career development for women in surgical subspecialties. Behmer Hansen et al. found that, compared to male counterparts, women who were fellowshiptrained were more likely to hold an academic rank as assistant professor rather than professor. Additionally, men had higher scholarly productivity in every subspecialty of neurosurgery despite proportionally more females completing neurosurgical fellowships and having similar or higher levels of research output later in their careers..$^{22}$ Within other specialties, such as otolaryngology, male PIs were found to have higher average NIH funding totals compared to female PIs, even when adjusted for academic rank and active years. ${ }^{23}$ Men also tended to receive more prestigious grants or grants with more funding compared to women in several specialties. ${ }^{23-26}$ Furthermore, an analysis of research grant applications for Harvard Medical School faculty found that female faculty had fewer grant submissions overall after controlling for academic rank. ${ }^{27}$

The impact of female neurosurgeons with reduced research funding may contribute to the gender gap in authorship observed in journals such as Neurosurgery and the Journal of Neurosurgery. From 2003 to 2018, there were fewer female first and senior authors when compared to males (16\% and $10.8 \%$ ), although these percentages did increase linearly over time. Interestingly, it was found that women were more likely to coauthor with other females as the first or senior authors than with males. ${ }^{28}$ This could potentially exemplify a way to combat the gender discrepancies observed in research funding nationally; women supporting each other in their research may serve as a catalyst for greater interest and more applications for funding by practicing female neurosurgeons.

At least theoretically, funding access impacts research productivity, which impacts one's ability to rise through the ranks of academic neurosurgery. As of 2017, only $7.45 \%$ of faculty leaders were female and $5.84 \%$ were full professors in academic neurosurgery, although those numbers have slowly been increasing in recent years. ${ }^{5,29}$ Another study found that women do not advance as quickly in academic rank and are not compensated equally to their male counterparts in similar positions. ${ }^{30}$ There also 
TABLE 2. Distinct project-PI combinations awarded grant funding outside of the US (2012-2018)

\begin{tabular}{|c|c|c|c|c|c|c|c|}
\hline Project & $\begin{array}{l}\text { Gender } \\
\text { of PI }\end{array}$ & Degree & Country & Funder & Period & $\begin{array}{l}\text { Overall Project } \\
\quad \text { Funding }\end{array}$ & $\begin{array}{l}\text { Converted } \\
\text { Funding Amount }\end{array}$ \\
\hline $\begin{array}{l}\text { Mechanisms of therapeutic efficacy of deep brain stimulation in } \\
\text { Parkinson's disease }\end{array}$ & $M$ & $\mathrm{MD}$ & Canada & $\mathrm{ClHR}$ & $\begin{array}{c}2015- \\
2020\end{array}$ & $\begin{array}{c}688,229 \\
(2015 \text { CAD) }\end{array}$ & $\begin{array}{c}639,112 \\
(2019 \text { USD) }\end{array}$ \\
\hline $\begin{array}{l}\text { Improving the safety and efficacy of intraventricular neurosur- } \\
\text { gery via robotics }\end{array}$ & $M$ & MD & Canada & $\mathrm{NIH}$ & $\begin{array}{l}2017- \\
2021\end{array}$ & - & - \\
\hline $\begin{array}{l}\text { Metabolic and functional correlates in spinal cord compression } \\
\text { measured by magnetic resonance imaging }\end{array}$ & $M$ & $\mathrm{MD}, \mathrm{MSc}$ & Canada & $\mathrm{ClHR}$ & $\begin{array}{l}2011- \\
2015\end{array}$ & $\begin{array}{c}325,808 \\
(2011 \mathrm{CAD})\end{array}$ & $\begin{array}{c}371,281 \\
(2019 \text { USD) }\end{array}$ \\
\hline $\begin{array}{l}\text { Multimodal identification of the neurovascular coupling within } \\
\text { the epileptogenic network }\end{array}$ & $M$ & $\begin{array}{l}\text { MD, MSc, } \\
\text { FRCS }\end{array}$ & Canada & $\mathrm{ClHR}$ & $\begin{array}{c}2014- \\
2018\end{array}$ & $\begin{array}{c}486,582 \\
(2014 \text { CAD) }\end{array}$ & $\begin{array}{c}494,846 \\
(2019 \text { USD) }\end{array}$ \\
\hline $\begin{array}{l}\text { Development and clinical translation of a Raman spectroscopy } \\
\text { imaging technique to increase the extent of tumor resection in } \\
\text { glioma surgery }\end{array}$ & $M$ & $\begin{array}{l}\text { MD, MSc, } \\
\text { FRCS }\end{array}$ & Canada & $\mathrm{ClHR}$ & $\begin{array}{c}2016- \\
2019\end{array}$ & $\begin{array}{c}264,929 \\
(2016 \text { CAD })\end{array}$ & $\begin{array}{c}203,739 \\
(2019 \text { USD) }\end{array}$ \\
\hline $\begin{array}{l}\text { Role of the basal ganglia in inhibiting and promoting voluntary } \\
\text { movements }\end{array}$ & $\mathrm{F}$ & $\mathrm{MD}, \mathrm{MSc}$ & Canada & $\mathrm{ClHR}$ & $\begin{array}{c}2014- \\
2016\end{array}$ & $\begin{array}{c}225,000 \\
(2014 \mathrm{CAD})\end{array}$ & $\begin{array}{c}228,821 \\
(2019 \text { USD) }\end{array}$ \\
\hline $\begin{array}{l}\text { Functional connectivity of neuronal networks in childhood } \\
\text { epilepsy }\end{array}$ & $M$ & $\mathrm{MD}, \mathrm{PhD}$ & Canada & $\mathrm{ClHR}$ & $\begin{array}{c}2012- \\
2015\end{array}$ & $\begin{array}{c}150,000 \\
(2012 \text { CAD) }\end{array}$ & $\begin{array}{c}163,519 \\
(2019 \text { USD) }\end{array}$ \\
\hline $\begin{array}{l}\text { Informing choice for neurotechnological innovation in pediatric } \\
\text { epilepsy surgery }\end{array}$ & $M$ & $\mathrm{MD}, \mathrm{PhD}$ & Canada & $\mathrm{NIH}$ & $\begin{array}{c}2018- \\
2021\end{array}$ & - & - \\
\hline $\begin{array}{l}\text { Low grade glioma: image- and population-based studies of } \\
\text { clinical outcomes }\end{array}$ & $M$ & $\mathrm{MD}, \mathrm{PhD}$ & Sweden & SRC & $\begin{array}{c}2018- \\
2020\end{array}$ & $\begin{array}{l}16,650,000 \\
(2018 \text { SEK })^{*}\end{array}$ & $\begin{array}{c}2,068,674 \\
(2019 \text { USD) }\end{array}$ \\
\hline $\begin{array}{l}\text { Improving infant hydrocephalus outcomes in Uganda: predicting } \\
\text { developmental outcomes and identifying patients at risk for early } \\
\text { treatment failure after ETVICPC }\end{array}$ & $M$ & $\mathrm{MD}, \mathrm{PhD}$ & Canada & $\mathrm{NIH}$ & $\begin{array}{c}2016- \\
2023\end{array}$ & - & - \\
\hline $\begin{array}{l}\text { Role of the basal ganglia in inhibiting and promoting voluntary } \\
\text { movements }\end{array}$ & M & $\mathrm{MD}, \mathrm{PhD}$ & Canada & $\mathrm{ClHR}$ & $\begin{array}{l}2014- \\
2016\end{array}$ & $\begin{array}{c}225,000 \\
(2014 \text { CAD) }\end{array}$ & $\begin{array}{c}228,821 \\
(2019 \text { USD) }\end{array}$ \\
\hline Deep brain stimulation for Alzheimer's disease & M & $\mathrm{MD}, \mathrm{PhD}$ & Canada & $\mathrm{NIH}$ & $\begin{array}{l}2012- \\
2017\end{array}$ & - & - \\
\hline $\begin{array}{l}\text { Radiosurgery vs lobectomy for temporal lobe epilepsy: phase } 3 \\
\text { clinical trial }\end{array}$ & M & MD & India & $\mathrm{NIH}$ & $\begin{array}{c}2009- \\
2014\end{array}$ & - & - \\
\hline $\begin{array}{l}\text { Wellcome Trust Clinical PhD Programme at Imperial College Lon- } \\
\text { don: the application of robotics to minimally invasive neurosurgery }\end{array}$ & M & $\begin{array}{l}\text { MBBS, } \\
\text { PhD }\end{array}$ & UK & WT & $\begin{array}{c}2012- \\
2015\end{array}$ & - & - \\
\hline $\begin{array}{l}\text { Improving infant hydrocephalus outcomes in Uganda: predicting } \\
\text { developmental outcomes and identifying patients at risk for early } \\
\text { treatment failure after ETVICPC }\end{array}$ & $\mathrm{F}$ & $\mathrm{MD}, \mathrm{MPH}$ & Uganda & $\mathrm{NIH}$ & $\begin{array}{c}2018- \\
2023\end{array}$ & - & - \\
\hline $\begin{array}{l}\text { Informing choice for neurotechnological innovation in pediatric } \\
\text { epilepsy surgery }\end{array}$ & M & $\begin{array}{l}\text { MD, } \\
\text { MHSc }\end{array}$ & Canada & $\mathrm{NIH}$ & $\begin{array}{c}2018- \\
2021\end{array}$ & - & - \\
\hline Engineered potassium channel gene therapy for epilepsy & M & MD & UK & MRC & $\begin{array}{c}2018- \\
2022\end{array}$ & $\begin{array}{c}1,991,577 \\
(2018 \mathrm{GBP})\end{array}$ & $\begin{array}{l}2,736,855 \\
\text { (2019 USD) }\end{array}$ \\
\hline $\begin{array}{l}\text { Radiosurgery vs lobectomy for temporal lobe epilepsy: phase } 3 \\
\text { clinical trial }\end{array}$ & M & MBBS & India & $\mathrm{NIH}$ & $\begin{array}{c}2009- \\
2014\end{array}$ & - & - \\
\hline $\begin{array}{l}\text { Metastatic epidural spinal cord compression: development of } \\
\text { clinical prediction rules to assess health-related quality of life } \\
\text { and survival in surgically treated patients }\end{array}$ & $\mathrm{F}$ & MD & Canada & $\mathrm{ClHR}$ & $\begin{array}{c}2016- \\
2019\end{array}$ & $\begin{array}{c}165,000 \\
(2016 \text { CAD) }\end{array}$ & $\begin{array}{c}126,890 \\
(2019 \text { USD) }\end{array}$ \\
\hline $\begin{array}{l}\text { Development and clinical translation of a Raman spectroscopy } \\
\text { imaging technique to increase the extent of tumor resection in } \\
\text { glioma surgery }\end{array}$ & M & $\mathrm{MD}, \mathrm{PhD}$ & Canada & $\mathrm{ClHR}$ & $\begin{array}{c}2016- \\
2019\end{array}$ & $\begin{array}{c}264,929 \\
(2016 \text { CAD) }\end{array}$ & $\begin{array}{c}203,739 \\
(2019 \text { USD) }\end{array}$ \\
\hline Optical guidance for safe and effective brain tumor biopsy & M & $\mathrm{MD}, \mathrm{PhD}$ & Canada & $\mathrm{ClHR}$ & $\begin{array}{l}2014- \\
2017\end{array}$ & $\begin{array}{c}211,407 \\
(2014 \mathrm{CAD})\end{array}$ & $\begin{array}{c}214,997 \\
(2019 \text { USD) }\end{array}$ \\
\hline $\begin{array}{l}\text { Radiosurgery vs lobectomy for temporal lobe epilepsy: phase } 3 \\
\text { clinical trial }\end{array}$ & $\mathrm{F}$ & $\mathrm{MCh}$ & India & $\mathrm{NIH}$ & $\begin{array}{c}2009- \\
2014\end{array}$ & - & - \\
\hline $\begin{array}{l}\text { Innovative approaches for characterisation and treatment of } \\
\text { olfactory neuroblastoma }\end{array}$ & $\mathrm{F}$ & $\mathrm{MBChB}$ & UK & MRC & $\begin{array}{c}2015- \\
2018\end{array}$ & $\begin{array}{l}291,761.25 \\
(2015 \text { GBP })\end{array}$ & $\begin{array}{c}490,374 \\
(2019 \text { USD) }\end{array}$ \\
\hline
\end{tabular}

$\mathrm{CAD}=$ Canadian dollar; $\mathrm{CPC}=$ choroid plexus cauterization; $\mathrm{ETV}=$ endoscopic third ventriculostomy; $\mathrm{GBP}=$ British pound; SEK = Swedish krona.

* This funding amount was converted to overall project funding by multiplying by study duration. 
TABLE 3. Characteristics of international fellowships won by women

\begin{tabular}{|c|c|}
\hline Variable & Value (\%) \\
\hline \multicolumn{2}{|l|}{ Fellowship award characteristics $(n=22)$} \\
\hline \multicolumn{2}{|l|}{ Award } \\
\hline AANS international traveling fellowship & $2(9.1)$ \\
\hline $\begin{array}{l}\text { AANS/CNS joint pediatrics international traveling } \\
\text { fellowship }\end{array}$ & $7(31.8)$ \\
\hline $\begin{array}{l}\text { WINS/Greg Wilkins-Barrick Chair Visiting } \\
\text { International Surgeon }\end{array}$ & $13(59.1)$ \\
\hline \multicolumn{2}{|l|}{ Award year } \\
\hline $2001-2005$ & $1(4.5)$ \\
\hline $2006-2010$ & $3(13.6)$ \\
\hline 2011-2015 & $8(36.4)$ \\
\hline $2016-2019$ & $10(45.5)$ \\
\hline \multicolumn{2}{|l|}{ Grant awardee characteristics $(n=21)$} \\
\hline \multicolumn{2}{|l|}{ Home country } \\
\hline India & $4(19.0)$ \\
\hline Indonesia & $3(14.3)$ \\
\hline Germany, Philippines, Russia, Spain* & $8(38.1)$ \\
\hline Armenia, China, Cuba, Rwanda, Saudi Arabia, UK† & $6(28.6)$ \\
\hline \multicolumn{2}{|l|}{ Degree } \\
\hline $\begin{array}{l}\text { Medical degree and advanced degree (MS, PhD, } \\
\text { DNB) }\end{array}$ & $6(28.6)$ \\
\hline
\end{tabular}

* Two female grant awardees from each country, 8 total.

† One female grant awardee from each country, 6 total.

is a lack of women in positions of surgical leadership as editorial board members, at neurosurgical conferences, or in society/association positions (AANS, CNS, Society of Neurological Surgeons, and American Board of Neurological Surgery)., ${ }^{4,31}$ Women made up only $19 \%$ of the board members in high-impact general surgery journals; we can envision that this number may be even lower for neurosurgery journals, although this remains speculative until further investigated..$^{32}$ While more women are entering the field of neurosurgery, the results of our study and others imply unequal access to opportunities in academic neurosurgery when compared to male counterparts. The reasons for this are multifactorial and warrant further inquiry, as research, leadership, and academia are deeply interdependent on each other for professional success and advancement in neurosurgery.

The lack of female neurosurgeons also makes it more difficult to establish a supportive network of mentorship and sponsorship, two factors that have been deemed important to increasing success in academia and research. ${ }^{4,14}$ These same challenges are likely to affect practicing female neurosurgeons who wish to receive funding to pursue research in this field. Additionally, the role of childbearing and familial responsibilities often fall disproportionately on these female surgeons, particularly with respect to time conflicts and time spent in clinic not being perceived as highly valued for advancement in academia. ${ }^{33-36}$

On the international scale, women comprise $0 \%-40 \%$ of board-certified neurosurgeons in more than 40 coun- tries worldwide. ${ }^{37-40}$ However, we noted that the majority of grants were awarded to neurosurgeon-researchers in the US. This discrepancy between number of grants awarded and percentage of female neurosurgeons may be a result of differences in residency structure, with US residencies possibly having more mandatory research components built into their curricula compared with other countries. ${ }^{41-43}$ Globally, conditions appear to be improving for female neurosurgeons as medical systems adopt gender-inclusive policies and become more culturally accepting, but men continue to hold more professorships and encounter fewer obstacles to work-family relationships, confidence, compensation, and professional stigma throughout training as a whole. ${ }^{37-40}$

Although international traveling fellowships ultimately may not be a marker for academic productivity, they are an important step in careers for international women neurosurgeons. At first glance, an analysis of international traveling fellowship data shows that more women have been selected as fellowship recipients over time, with women now constituting $45.5 \%$ of the overall cohort of international traveling fellows within the past 5 years (Table 3 ). However, when we analyzed traveling fellowships separately, there was no statistically significant difference in the proportion of AANS international traveling fellowships and AANS/CNS joint pediatrics international traveling fellowships awarded to women in the past 2 decades (Fig. 2).

It appears that more women have joined the ranks of traveling fellowship awardees overall, likely due to the creation of awards such as the WINS/Greg Wilkins-Barrick Chair Visiting International Surgeon Award in 2014, which selects 1 or 2 female neurosurgeons annually. ${ }^{19} \mathrm{~A}$ potential explanation for this finding is that women are applying for the other international traveling fellowship scholarships but are not being awarded as often. Another possibility is that women are not applying to the other international fellowships as often as the fellowships designated for female neurosurgeons.

We propose the following policy solutions that international neurosurgical societies can implement to augment global neurosurgery research efforts for female neurosurgeons (Fig. 3). First, the establishment of quarterly or monthly grant-writing workshops led by previous awardees that are recorded for an international audience may prove particularly useful for new applicants looking to break into research. Second, building mentor-mentee networks between successful women surgeon-scientists and early career trainees can empower greater numbers of female neurosurgeons to pursue research and offer guidance for navigating academia. Lastly, we propose targeted outreach by international fellowship directors to female neurosurgeons from underrepresented countries from South America and Africa to gain exposure to surgical research. ${ }^{43}$ Implementation of these policies can build a foundation for more women neurosurgeons to advance the field internationally.

\section{Limitations}

Limitations to our study include those inherent to the NIH and World RePORTER tools. Because neither tool 


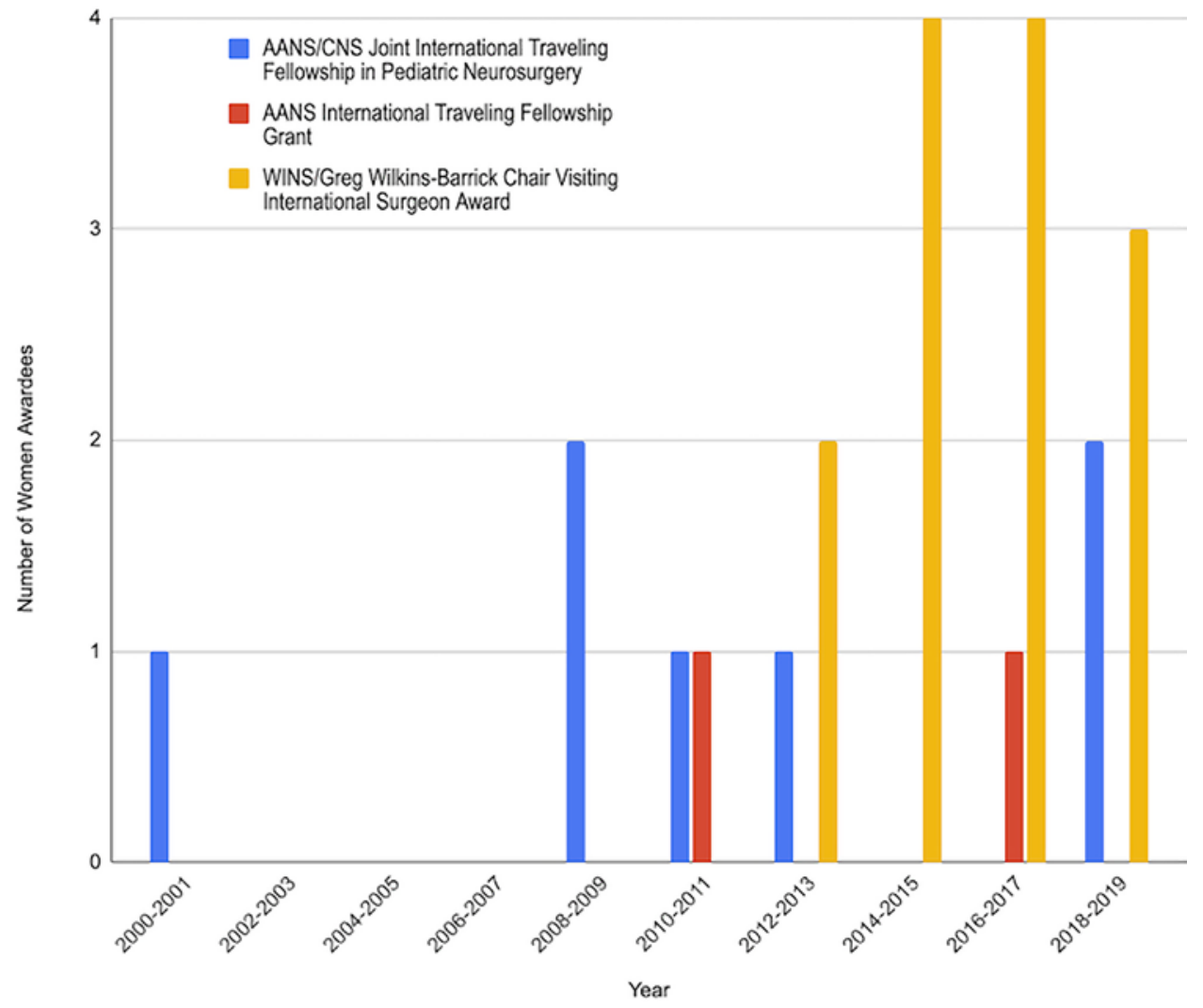

FIG. 2. Analysis of trends in international traveling fellowship awardees over time.

provides data on rejected grant applications, we were unable to analyze trends in the total female neurosurgery grant application rates. Moreover, because our analysis on US national data was limited to public grants awarded

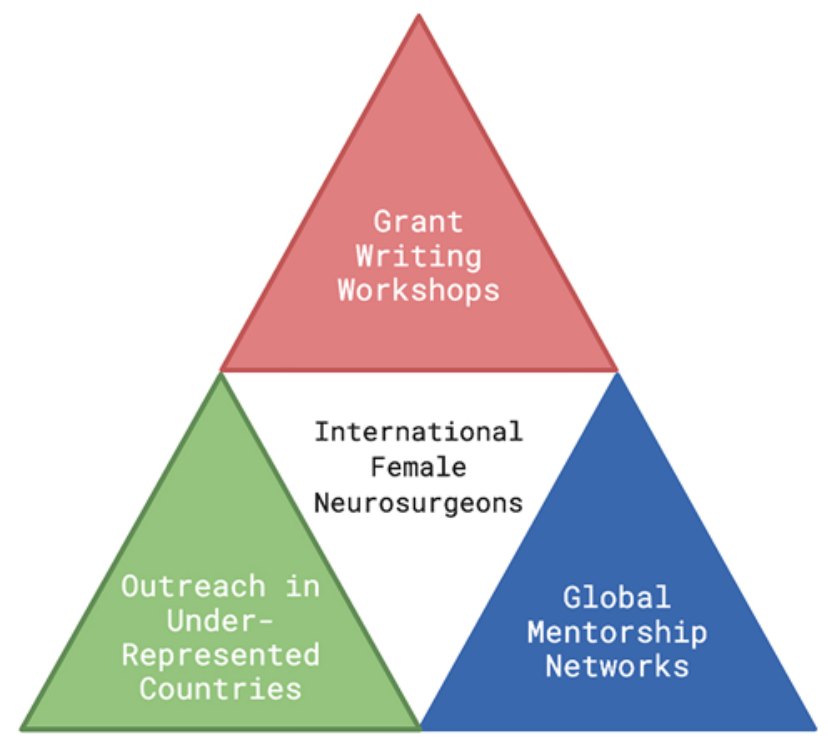

FIG. 3. Proposed policy solutions to promote grant funding for women neurosurgeons internationally. Made in CBioRender - biorender.com. by the NIH, our results do not include funding from other public agencies (National Science Foundation, Department of Defense, etc.) and private institutions. Our analysis on international data was limited by the greater variability in international reporting standards, which biased our sample against funding agencies that underreported funding allocation. While these limitations are important to acknowledge, we do not believe they significantly detract from our main findings.

\section{Conclusions}

Over the past decade funding has increased in neurosurgery without a concordant increase in funding awarded to women. Recognition of this trend is essential to focus efforts on research career development opportunities for female neurosurgery residents and faculty. Worldwide, female neurosurgeons head one-fifth of the funded project leads. Overall, women have made noteworthy progress in advancing the field of neurosurgery and achieving equality in the last few decades. However, our data indicate that there is still work to be done in supporting women to actualize their full potential. With effort, we wholeheartedly believe in the future that Spetzler envisioned in which "gender is less important than the overarching fact that we are all just neurosurgeons." ${ }^{4}$

\section{References}

1. Association of American Medical Colleges. The Complexi- 
ties of Physician Supply and Demand. Projections From 2018 to 2033. AAMC; 2020. Accessed January 13, 2021. https://www.aamc.org/system/files/2020-06/stratcommaamc-physician-workforce-projections-june-2020.pdf

2. Association of American Medical Colleges. 2019 fall applicant, matriculant, and enrollment data tables. AAMC; 2019. Accessed January 13, 2021. https://www.aamc. org/system/files/2019-12/2019\%20AAMC\%20Fall\%20 Applicant $\% 2 \mathrm{C} \% 20$ Matriculant $\% 2 \mathrm{C} \% 20$ and $\% 20$ Enrollment\%20Data\%20Tables_0.pdf

3. Agarwal N, Norrmén-Smith IO, Tomei KL, et al. Improving medical student recruitment into neurological surgery: a single institution's experience. World Neurosurg. 2013;80(6): 745-750.

4. Benzil DL, Abosch A, Germano I, et al. The future of neurosurgery: a white paper on the recruitment and retention of women in neurosurgery. J Neurosurg. 2008;109(3):378-386.

5. Odell T, Toor H, Takayanagi A, et al. Gender disparity in academic neurosurgery. Cureus. 2019;11(5):e4628.

6. Karsy M, Henderson F, Tenny S, et al. Attitudes and opinions of US neurosurgical residents toward research and scholarship: a national survey. J Neurosurg. 2018;131(1):252-263.

7. Cuoco JA, Klein BJ, Kar A, et al. Factors affecting R01 grant funding among academic neurosurgeons over the last decade. Ann Med Surg (Lond). 2020;55:260-264.

8. Jahangiri A, Flanigan PM, Arnush M, et al. From bench to bedside: trends in National Institutes of Health funding for neurosurgeons from 1991 to 2015. J Neurosurg. 2020;133(3): $865-874$

9. Neumayer L, Kaiser S, Anderson K, et al. Perceptions of women medical students and their influence on career choice. Am J Surg. 2002;183(2):146-150.

10. Dixon A, Silva NA, Sotayo A, Mazzola CA. Female medical student retention in neurosurgery: a multifaceted approach. World Neurosurg. 2019;122:245-251.

11. Jagsi R, Griffith KA, DeCastro RA, Ubel P. Sex, role models, and specialty choices among graduates of US medical schools in 2006-2008. J Am Coll Surg. 2014;218(3):345-352.

12. Cronan-Hillix T, Gensheimer LK, Cronan-Hillix WA, Davidson WS. Students' views of mentors in psychology graduate training. Teach Psychol. 1986;13(3):123-127.

13. Gibson SK. Being mentored: the experience of women faculty. J Career Dev. 2004;30(3):173-188.

14. Long JS, McGinnis R. The effects of the mentor on the academic career. Scientometrics. 1985;7(3):255-280.

15. National Institutes of Health. NIH Research Portfolio Online Reporting Tools (RePORT) Manual. NIH; 2018. Accessed January 13, 2021. https://projectreporter.nih.gov/ RePORTER_Manual_files/RePORTERManual.pdf

16. National Institutes of Health. World research portfolio online reporting tools. Accessed January 13, 2021. https://worldreport.nih.gov/app/\#!/about

17. American Association of Neurological Surgeons. AANS International Visiting Surgeon Fellowship. Accessed January 13, 2021. https://www.aans.org/en/Membership/InternationalActivities/International-Visiting-Surgeon-Fellowship

18. AANS/CNS Section on Pediatric Neurological Surgery. International Traveling Fellowship in Pediatric Neurosurgery. Accessed January 13, 2021. https://pedsneurosurgery.org/ grants-fellowships/international-traveling-fellowship-inpediatric-neurosurgery/

19. Women in Neurosurgery. WINS/Greg Wilkins-Barrick Chair Visiting International Surgeon Award. Accessed January 13, 2021. http://www.neurosurgerywins.org/visiting-surgeonfellowships

20. Federal Reserve Bank of Minneapolis. Consumer Price Index, 1913-. Accessed January 31, 2021. https://www.minneapolisfed.org/about-us/monetary-policy/inflation-calculator/ consumer-price-index-1913-
21. Exchange Rates. Accessed January 13, 2021. https://x-rates. $\mathrm{com} /$

22. Behmer Hansen RT, Silva NA, Cuevas R, et al. Fellowship, gender, and scholarly productivity: trends among academic neurosurgeons in the US. J Neurosurg. Published online August 28, 2020. doi:10.3171/2020.5.JNS20577

23. Eloy JA, Svider PF, Kovalerchik O, et al. Gender differences in successful NIH grant funding in otolaryngology. Otolaryngol Head Neck Surg. 2013;149(1):77-83.

24. Berg EJ, Ashurst J. Patterns of recent National Institutes of Health (NIH) funding in general surgery: analysis using the NIH RePORTER system. Cureus. 2019;11(6):e4938.

25. Silvestre J, Ahn J, Levin LS. National Institutes of Health funding to departments of orthopaedic surgery at U.S. medical schools. J Bone Joint Surg Am. 2017;99(2):e5.

26. Carnevale M, Phair J, Batarseh P, et al. Gender disparities in academic vascular surgeons. J Vasc Surg. 2020;72(4):14451450.

27. Waisbren SE, Bowles H, Hasan T, et al. Gender differences in research grant applications and funding outcomes for medical school faculty. J Womens Health (Larchmt). 2008;17(2): 207-214.

28. Aslan A, Kuzucu P, Karaaslan B, Borcek AO. Women in neurosurgery: gender differences in authorship in high-impact neurosurgery journals through the last two decades. World Neurosurg. 2020;138:374-380.

29. Sexton KW, Hocking KM, Wise E, et al. Women in academic surgery: the pipeline is busted. J Surg Educ. 2012;69(1): 84-90.

30. Ash AS, Carr PL, Goldstein R, Friedman RH. Compensation and advancement of women in academic medicine: is there equity? Ann Intern Med. 2004;141(3):205-212.

31. Silva N, Cerasiello S, Semonche A, et al. Gender representation at neurological surgery conferences. World Neurosurg. 2019;129:453-459.

32. Harris CA, Banerjee T, Cramer M, et al. Editorial (spring) board? Gender composition in high-impact general surgery journals over 20 years. Ann Surg. 2019;269(3):582-588.

33. Colletti LM, Mulholland MW, Sonnad SS. Perceived obstacles to career success for women in academic surgery. Arch Surg. 2000;135(8):972-977.

34. Jolly S, Griffith KA, DeCastro R, et al. Gender differences in time spent on parenting and domestic responsibilities by high-achieving young physician-researchers. Ann Intern Med. 2014;160(5):344-353.

35. Kato Y, Mihara C, Matsuyama J, et al. Role of women in medicine: a look at the history, the present condition and the future status of women in the surgical field, especially neurosurgery. Minim Invasive Neurosurg. 2004;47(2):65-71.

36. Thompson-Burdine JA, Telem DA, Waljee JF, et al. Defining barriers and facilitators to advancement for women in academic surgery. JAMA Netw Open. 2019;2(8):e1910228.

37. Fujimaki T, Shibui S, Kato Y, et al. Working conditions and lifestyle of female surgeons affiliated to the Japan Neurosurgical Society: findings of individual and institutional surveys. Neurol Med Chir (Tokyo). 2016;56(11):704-708.

38. Palanisamy D, Battacharjee S. What it is to be a woman neurosurgeon in India: a survey. Asian J Neurosurg. 2019;14(3): 808-814.

39. Steklacova A, Bradac O, de Lacy P, Benes V. E-WIN Project 2016: evaluating the current gender situation in neurosurgery across Europe-an interactive, multiple-level survey. World Neurosurg. 2017;104:48-60.

40. Wilkes FA, Akram H, Hyam JA, et al. Publication productivity of neurosurgeons in Great Britain and Ireland. J Neurosurg. 2015;122(4):948-954.

41. Burkhardt JK, Zinn PO, Bozinov O, et al. Neurosurgical education in Europe and the United States of America. Neurosurg Rev. 2010;33(4):409-417. 
42. Martin M, Burn SC. Neurosurgical residency in the United States: a trainee's experience. Acta Neurochir (Wien). 2005; 147(11):1211-1212.

43. Mukhopadhyay S, Punchak M, Rattani A, et al. The global neurosurgical workforce: a mixed-methods assessment of density and growth. J Neurosurg. 2019;130(4):1142-1148.

44. Spetzler RF. Progress of women in neurosurgery. Asian J Neurosurg. 2011;6(1):6-12.

\section{Disclosures}

The authors report no conflict of interest concerning the materials or methods used in this study or the findings specified in this paper.

\section{Author Contributions}

Conception and design: Wang, Bhandarkar. Acquisition of data: Wang, Bhandarkar, Bauman, Riviere-Cazaux. Analysis and interpretation of data: Wang, Bhandarkar. Drafting the article: Wang, Bhandarkar, Bauman, Riviere-Cazaux. Critically revising the article: all authors. Reviewed submitted version of manuscript: all authors. Approved the final version of the manuscript on behalf of all authors: Clarke. Statistical analysis: Bhandarkar. Administrative/technical/material support: Clarke. Study supervision: Clarke.

\section{Correspondence}

Michelle J. Clarke: Mayo Clinic, Rochester, MN. clarke. michelle@mayo.edu. 